\title{
PENGARUH BAURAN PEMASARAN TERHADAP PENGAMBILAN KEPUTUSAN MENGGUNAKAN JASA BIMBINGAN BELAJAR PRIMAGAMA
}

(Studi Kasus Pada Siswa Lembaga Bimbingan Belajar Primagama Cabang Jember)

\author{
Diccit Darohma Jutisa ${ }^{1}$, Joko Widodo ${ }^{1}$, Sri Wahyuni ${ }^{1}$ \\ ${ }^{1}$ Program Studi Pendidikan Ekonomi, Fakultas Keguruan dan Ilmu Pendidikan, Universitas Jember \\ e-mail: ddarohma@gmail.com
}

\begin{abstract}
Abstrak
Bauran pemasaran jasa pendidikan pada lembaga bimbingan belajar merupakan serangkaian alat pemasaran yang dilakukan untuk membentuk karakteristik program layanan jasa yang ditawarkan kepada konsumen. Keputusan siswa menggunakan jasa bimbingan belajar pada Lembaga Primagama dilatar belakangi dengan adanya kebutuhan siswa untuk menambah ilmu pengetahuan akademik yang sebelumnya telah didapatkan di pendidikan formal. Adanya Ujian Nasional (UN) dan seleksi masuk di Perguruan Tinggi Negeri (PTN) melalui tes tulis menjadikan lembaga bimbingan belajar semakin dibutuhkan keberadaanya bagi siswa untuk mencapai lulus UN dan diterima di PTN. Melalui bauran pemasaran, Lembaga bimbingan belajar sebagai pelaku usaha perlu melakukan strategi yang tepat untuk dapat mencapai sasaran dalam pasar sehingga konsumen melakukan keputusan pembelian jasa layanan tersebut.Tujuan penelitian ini adalah untuk mengetahui besarnya pengaruh bauran pemasaran terhadap pengambilan keputusan menggunakan jasa bimbingan belajar Primagama Cabang Jember. Adapun penentuan lokasi dalam penelitian ini menggunakan purposive area yakni seluruh siswa jenjang SMA program bimbingan reguler pada lembaga bimbingan belajar Primagama Cabang Jember dengan jumlah responden sebanyak 51 orang. Metode yang digunakan adalah analisis deskriptif dan inferensial menggunakan regresi linier sederhana. Hasil Uji $F$ menunjukkan $\mathrm{F}_{\text {hitung }}=240,499>\mathrm{F}_{\text {tabel }}=4,03$ dengan tingkat signifikansi $0,000<a=0,05$ dengan persamaan regresi sederhana $\hat{Y}=3,454+0,226 X$. Hasil perhitungan koefisien determinasi $\left(\mathrm{R}^{2}\right)$ sebesar 0,831 , hal tersebut menunjukkan bahwa besarnya persentase pengaruh bauran pemasaran terhadap pengambilan keputusan siswa menggunakan jasa bimbingan belajar Primagama Cabang Jember sebesar 83,1\%, sedangkan sisanya yaitu $16,9 \%$ dipengaruhi oleh variabel bebas lain yang tidak diteliti dalam penelitian ini seperti pengaruh perorangan, kondisi ekonomi, dll. Berdasarkan hasil yang diperoleh diatas dapat disimpulkan bahwa variabel bauran pemasaran meliputi produk (Product), promosi (promotion), lokasi (place), harga (price), orang/SDM (people), bukti fisik (physical evidence), dan proses (process) dapat memengaruhi keputusan konsumen.
\end{abstract}

Kata Kunci: Bauran Pemasaran, Keputusan Menggunakan Jasa.

\section{PENDAHULUAN}

Lembaga bimbingan belajar tergolong dalam pendidikan nonformal yang kegiatannya dilakukan untuk memberikan bantuan kepada siswa dalam hal untuk memperkaya khasanah ilmu pengetahuan yang dapat digunakan untuk mempersiapkan ujian akhir semester atau digunakan untuk persiapan ke jenjang pendidikan selanjutnya. Yusuf \& Nurihsan (2012:78) menjelaskan bahwa lembaga bimbingan belajar adalah sebuah lembaga yang dibuat untuk membantu siswa dalam menempuh pendidikan. Lembaga bimbingan belajar digunakan sebagai tempat larinya siswa yang kurang menguasai pelajaran yang sebelumnya telah didapatkan di lembaga formal.

Lembaga bimbingan belajar dijadikan sebagai alternatif pilihan siswa untuk belajar diluar sekolah. Siswa memperoleh materi pelajaran tambahan secara mendalam dari lembaga bimbingan belajar yang menyebabkan siswa dapat terbantu untuk menguasai pelajaran-pelajaran disekolah. Adanya Ujian Nasional (UN) dan seleksi masuk di Perguruan Tinggi Negeri (PTN) melalui tes tulis menjadikan lembaga bimbingan belajar semakin dibutuhkan keberadaanya bagi siswa untuk mencapai lulus UN dan diterima di Perguruan Tinggi Negeri (PTN). Sehubungan dengan kondisi tersebut, keberadaan lembaga bimbingan belajar banyak didirikan di berbagai daerah .

Kemunculan lembaga bimbingan belajar sebagai lembaga usaha diperlukan untuk mengelola bauran pemasaran yang dapat digunakan sebagai sarana untuk dapat mencapai sasaran dalam pasar. Bauran pemasaran 
merupakan indikator dari strategi pemsaran yang dijadikan sebagai alat pemasar untuk menarik minat konsumen sehingga melakukan keputusan pembelian dengan pertimbangan elemen dalam bauran pemasaran. Lembaga pendidikan perlu memerhatikan indikator bauran pemasaran jasa pendidikan yang terdiri dari 7 elemen. Seperti yang diungkapkan oleh Alma (2014 : 382) "Elemen-elemen strategi bauran pemasaran terdiri atas Produk (Product), Promosi (Promotion), Lokasi (Place), Harga (Price), Orang/SDM (People), Bukti Fisik (Physical Evidence), Proses (Process).

Bauran pemasaran pada hakikatnya merupakan serangkaian strategi pemasaran yang ditempuh dalam upaya untuk mencapai tujuan tertentu. Untuk menentukan strategi dan bauran pemasaran terbaik perusahaan melibatkan analisis, perencanaan, implementasi dan kendali pemasaran. Lupiyoadi (2013:92) menyatakan bahwa bauran pemasaran merupakan perangkat/alat bagi pemasar yang terdiri atas berbagai unsur suatu program pemasaran yang perlu dipertimbangkan agar implementasi strategi pemasaran dan penentuan posisi yang ditetapkan dapat berjalan sukses. Pemaparan teori serupa diungkapkan oleh Alma \& Hurriyati (2008:154) Menyatakan bahwa bauran pemasaran jasa pendidikan adalah elemen-elemen organisasi pendidikan yang dapat dikontrol oleh organisasi-organisasi dalam melakukan komunikasi dengan peserta didik dan akan dipakai untuk memuaskan peserta didik.

Indikator bauran pemasaran jasa pada lembaga bimbingan belajar terkait dengan keunggulan produk yang ditawarkan, penempatan lokasi yang mudah dijangkau oleh konsumen, penetapan harga yang disesuaikan, promosi yang dilakukan secara efektif dengan memanfaatkan berbagai media, tipe kualitas dan Sumber daya manusia yang dilakukan saat memberikan pelayanan jasa, tahapan proses jasa yang dilakukan, serta bukti fisik berupa fasilitas, sarana prasarana yang dapat mendukung keputusan konsumen untuk menggunakan layanan jasa tersebut. Bauran pemasaran perlu diatur secara efektif oleh lembaga bimbingan belajar sebagai bahan merancang strategi pemasaran agar lembaga dapat memengaruhi siswa sebagai calon konsumen untuk membeli layanan jasa yang dipasarkan.

Persaingan yang semakin ketat terhadap pelaku bisnis jasa sejenis seperti pada lembaga bimbingan belajar juga perlu menjadi pertimbangan bagi para pelaku usaha untuk dapat mempertahankan usahanya. Para pelaku usaha perlu sering melakukan upgrading terhadap produk, bentuk layanan yang ditawarkan kepada konsumen dan aspek lainnya terkait dengan pengaruh bauran pemasaran agar konsumen dapat tertarik untuk memutuskan menggunakan jasa tersebut. Indikator dari bauran pemasaran sering kali menjadi bahan pertimbangan konsumen sebelum melakukan keputusan apakah dirinya akan memutuskan menggunakan layanan jasa tersebut. Nitisusastro (2013:197) menyatakan bahwa "Instrumen bauran pemasaran meliputi produk, harga, promosi, pendukung fisik, proses, dan orang dapat memengaruhi konsumen".

Keputusan siswa untuk memilih menggunakan jasa layanan bimbingan belajar tidak hanya dapat dipengaruhi faktor bauran pemasaran, namun juga dipengaruhi oleh beberapa pertimbangan berdasarkan indikator pada keputusan pembelian. Indikator tersebut terkait dengan pilihan produk melalui program layanan bimbingan belajar yang ditawarkan oleh lembaga, brand image yang dimiliki oleh lembaga bimbingan belajar, dan pertimbangan terkait dengan penempatan lokasi yang ditetapkan sebagai saluran distribusi saat membeli produk jasa.

Konsumen melakukan pengambilan keputusan terhadap suatu produk jasa dengan melakukan berbagai pertimbangan sebelumnya. Menurut Nitisusastro (2013:194) keputusan konsumen merupakan tahapan proses akhir dari serangkaian tahapan proses yang terjadi pada perilaku konsumen. Sebelum melakukan keputusan pembelian, konsumen mengalami dorongan untuk mempertimbangkan membeli suatu produk jasa tertentu dengan didasarkan pada kebutuhan. Tjiptono (2011:59) menyatakan, "seorang konsumen akan merasakan kebutuhan untuk membeli suatu produk jasa pada situasi "shortage" (Kebutuhan timbul karena konsumen tidak memiliki produk atau jasa tersebut). Setelah seseorang menyadari kebutuhan yang diperlukan, selanjutnya seseorang melakukan pencarian informasi berdasarkan dari pihak pemasar serta lingkungan yang sesuai dengan karakteristik terkait dengan ciri-ciri pembeli. Hal tersebut membentuk adanya perilaku konsumen saat melakukan keputusan membeli suatu produk.

Banyaknya lembaga bimbingan belajar yang bermunculan di Kabupaten Jember menyebabkan adanya persaingan yang ketat antar lembaga. Dengan demikian para lembaga bimbingan belajar perlu menawarkan program pelayanan yang menyesuaikan kebutuhan siswa sebagai konsumen. Selain itu, lembaga bimbingan 
belajar juga perlu memperhatikan manajemen pemasaran yang lebih baik dibandingkan dengan kompetitor pelaku usaha sejenis. Hal tersebut dimaksudkan agar siswa dapat terpengaruh untuk memutuskan bergabung dengan bimbingan belajar tersebut.

Salah satu lembaga yang telah menekuni usaha di bidang layanan bimbingan belajar di Kabupaten Jember adalah Lembaga Bimbingan Belajar Primagama Cabang Jember. Lembaga Bimbingan Belajar Primagama merupakan salah satu lembaga bimbingan belajar di Indonesia sudah mempunyai cakupan pasar diberbagai daerah. Lembaga Bimbingan Belajar merupakan lembaga bimbingan belajar bagi para pelajar di jenjang SD, SMP dan SMA hingga para alumni SMA yang memersiapkan untuk memasuki perguruan ting gi.

Berdasarkan observasi dan wawancara yang telah dilakukan oleh peneliti pada Bimbingan Belajar Primagama Cabang Jember. Diperoleh informasi bahwa Lembaga Bimbingan Belajar Primagama Cabang Jember merupakan lembaga bimbingan belajar yang sudah berdiri sejak tahun 1992. Dua puluh lima tahun semenjak berdirinya lembaga di Kabupaten Jember, Bimbingan Belajar Primagama Cabang Jember tetap mempertahankan eksistensinya dan mampu bersaing dengan kompetitor lembaga sejenis hingga saat ini. Hal tersebut dibuktikan dengan jumlah siswa yang bergabung kedalam lembaga primagama mencapai lebih dari 100 siswa setiap tahunnya yang terdiri dari siswa pada jenjang SD, SMP, SMA dan jenjang Alumni. Pada tahun 2017 jumlah siswa lembaga belajar primagama yang mengikuti program bimbingan reguler sebanyak 145 yang terdiri dari 26 siswa SD, 68 siswa SMP, dan 51 siswa SMA. Berdasarkan hasil observasi awal yang telah dilakukan, hal tersebut menarik untuk dilakukan penelitian guna untuk mengetahui adakah pengaruh dari bauran pemasaran yang dilakukan oleh lembaga primagama terhadap pengambilan keputusan siswa menggunakan jasa bimbingan belajar Primagama Cabang Jember.

Berdasarkan uraian yang telah dipaparkan diatas peneliti merasa tertarik untuk melakukan penelitian mengenai "Pengaruh Bauran pemasaran Terhadap Pengambilan Keputusan Menggunakan Jasa Bimbingan Belajar Primagama"(Studi Kasus pada Siswa Lembaga Bimbingan Belajar Primagama Cabang Jember).

\section{METODE}

Penelitian ini dilakukan dengan metode kuantitatif menggunakan analisis regresi linier sederhana. Peneliti ingin melakukan penelitian non eksperimental, yaitu penelitian yang hanya ingin mengetahui pengaruh variabel bauran pemasaran terhadap pengambilan keputusan konsumen menggunakan jasa bimbingan belajar Primagama. Adapun metode penentuan lokasi penelitian menggunakan purposive area, yaitu pemilihan tempat penelitian yang dengan disengaja ditentukan dan disesuaikan dengan pertimbangan tertentu yakni di Lembaga Bimbingan Belajar Primagama Cabang Jember. Metode pengumpulan data pada penelitian ini dengan menggunakan metode angket, metode wawancara, dan metode observasi. Penyebaran angket diberikan kepada seluruh populasi siswa jenjang SMA dengan program bimbingan reguler pada Bimbingan Belajar Primagama Cabang Jember pengisian kuisioner diberikan kepada seluruh populasi yang sebanyak 51 responden dikarenakan jumlah tersebut telah sesuai dengan syarat penentuan penelitian. Analisis data yang digunakan yaitu analisis deskriptif dan analisis inferensial. Analisis inferensial yang digunakan yaitu varian garis regresi, Uji F, dan koefisien determinasi, untuk memudahkan perhitungan analisis data maka peneliti menggunakan bantuan program SPSS 22.0 for windows.

\section{HASIL DAN PEMBAHASAN \\ Hasil Penelitian}

Hasil perhitungan analisis regresi linier sederhana dengan menggunakan program SPSS 22.0 for windows adalah sebagai berikut:

Tabel 1. Hasil analisis regresi linier sederhana

\begin{tabular}{lccc}
\hline Variabel & $\begin{array}{c}\text { Koefisien } \\
\text { Regresi }\end{array}$ & Sig. & Keterangan \\
\hline Konstan & 3,454 & - & - \\
Bauran Pemasaran & 0,226 & 0,000 & Signifikan \\
\hline
\end{tabular}

Berdasarkan Tabel diatas, hasil tersebut dapat diperoleh persamaan regersi linier sederhana sebagai 
berikut:

a. Nilai Konstanta

$$
\mathrm{Y}=3,454+0,226 \mathrm{X}+e
$$

Dari persamaan diatas didapatkan nilai konstanta sebesar 3,454 yang berarti bahwa jika nilai dari variabel independen bauran pemasaran sama dengan nol, maka keputusan menggunakan jasa (Y) adalah sebesar konstanta 3,454.

b. Koefisien regresi Bauran Pemasaran (X)

Nilai koefisien dari variabel bauran pemasaran adalah bernilai positif 0,226 yang berarti bahwa setiap kenaikan satu satuan variabel tersebut, akan meningkatkan keputusan menggunakan jasa sebesar 0,226.

Adapun hasil perhitungan untuk analisis varian garis regresi adalah sebagai berikut:

Tabel 2. Hasil interpretasi model summary

Model Summary

\begin{tabular}{|l|r|r|r|c|}
\hline Model & $\mathrm{R}$ & R Square & \multicolumn{1}{|c|}{$\begin{array}{c}\text { Adjusted R } \\
\text { Square }\end{array}$} & $\begin{array}{c}\text { Std. Error of the } \\
\text { Estimate }\end{array}$ \\
\hline 1 &, $911^{\mathrm{a}}$ &, 831 &, 827 & 1,21093 \\
\hline
\end{tabular}

a. Predictors: (Constant), $\mathrm{X}$

Diketahui hasil data yang didapatkan berdasarkan tabel diatas diketahui bahwa nilai $\mathrm{R}$ yang menunjukkan kuat tidaknya korelasi atau hubungan antara variabel bauran pemasaran (X) dengan variabel keputusan siswa menggunakan jasa bimbingan belajar Primagama (Y) yaitu sebesar 0,911. Hasil tersebut dikategorikan mempunyai hubungan yang sangat kuat.

Hasil $R$ Square seperti yang terlihat pada tabel 2 menunjukan nilai $R$ Square sebesar 0,831, sehingga hasil akhir setelah dimasukkan ke dalam rumus koefisien determinasi $\left(\mathrm{R}^{2}\right)$ adalah sebagai berikut:

$$
R \text { Square } \mathrm{X} 100 \%=0,831 \times 100 \%=83,1 \%
$$

Hal ini menunjukkan bahwa nilai peresentase pengaruh bauran pemasaran terhadap keputusan siswa menggunakan jasa bimbingan belajar Primagama menunjukkan secara keseluruhan berpengaruh sebesar $83,1 \%$. Adapun perhitungan dari $\mathrm{Uji} F$, diketahui nilai $\mathrm{F}_{\text {hitung }}$ sebagai berikut:

Tabel 3. Hasil uji F

ANOVA

\begin{tabular}{|ll|r|r|r|r|r|}
\hline Model & & Sum of Squares & df & Mean Square & \multicolumn{1}{c|}{ F } & Sig. \\
\hline 1 & Regression & 352,658 & 1 & 352,658 & 240,499 &, $000^{\mathrm{b}}$ \\
& Residual & 71,852 & 49 & 1,466 & & \\
Total & 424,510 & 50 & & & \\
\hline
\end{tabular}

a. Dependent Variable: Y

b. Predictors: (Constant), X

Berdasarkan data di atas, menunjukkan bahwa diketahui nilai $\mathrm{F}_{\text {hitung }}=240,499>\mathrm{F}_{\text {tabel }}=4,03$ dan nilai signifikansi sebesar $F=0,000<\alpha=0.05$. Hal tersebut menunjukkan bahwa variabel independen berpengaruh bersama-sama terhadap variabel dependen. Artinya, variabel bauran pemasaran memiliki pengaruh yang signifikan terhadap pengambilan keputusan menggunakan jasa bimbingan belajar Primagama Cabang Jember.

\section{Pembahasan}

Hasil analisis inferensial yang telah dijabarkan di atas diketahui bahwa proporsi pengaruh bauran pemasaran terhadap keputusan siswa menggunakan jasa bimbingan belajar Primagama sebesar 83,1\%. Dengan demikian, jawaban dari rumusan masalah pada penelitian ini yaitu adakah pengaruh yang signifikan bauran pemasaran terhadap pengambilan keputusan siswa menggunakan jasa Bimbingan Belajar Primagama Cabang Jember dapat terpenuhi. Melalui hasil penelitian ini, dapat diketahui bahwa adanya bauran pemasaran yang diterapkan oleh bimbingan Primagama dapat berpengaruh positif terhadap keputusan siswa menggunakan jasa bimbingan belajar. Secara inferensial, hasil yang menunjukkan pengaruh sebesar $83,1 \%$ dapat disimpulkan 
bahwa pengaruh bauran pemasaran terhadap keputusan menggunakan jasa bimbingan belajar Primagama dianggap tinggi. Hasil perhitungan analisis inferensial dengan metode regresi linier sederhana tersebut dikategorikan sangat tinggi karena integrasi indikator dalam Bauran Pemasaran mampu memengaruhi keputusan siswa menggunakan jasa bimbingan belajar di Lembaga Primagama Cabang Jember.

Konsumen tidak hanya membeli fisik dari produk saja, tetapi membeli manfaat dan nilai dari produk tersebut (Lupiyoadi , 2013:92). Produk jasa yang ditawarkan oleh bimbingan belajar Primagama adalah layanan program bimbingan belajar yang dibutuhkan dan dapat memuaskan keinginan oleh siswa. Kualitas layanan bimbingan belajar pada lembaga primagama dirasa berkualitas baik dan memiliki keunggulan sehingga cukup memberikan pengaruh terhadap keputusan siswa dalam memutuskan menggunakan jasa bimbingan belajar di Lembaga Primagama Cabang Jember. Adapun program-program unggulan yang dimiliki Lembaga Bimbingan Belajar Primagama dan tidak dimiliki oleh lembaga bimbingan lainnya adalah konsep belajar R.E.C, smart book, smart exercise, smart Test, metode belajar SMART Solution, smart consys, magasing, fisitaru, E-Learning Management System (EMS).

Promosi yang dilakukan oleh Lembaga Primagama secara informatif, menarik, dan tingkat kemunculan iklan dapat memberikan pengaruh terhadap pengambilan keputusan menggunakan jasa bimbingan belajar Primagama. pemanfaatan media sosial seperti sebagai media penyaluran promosi kepada konsumen melalui facebook, twitter, dan instagram dengan pemberian informasi bersifat membujuk (persuasive) dan pengingat (reminder) dapat memengaruhi keputusan siswa menggunakan jasa bimbingan belajar Primagama. Lembaga Primagama juga melakukan promosi dengan melakukan sosialisasi kesekolah-sekolah dengan melakukan pemberian brosur ke pada para siswa atau mengadakan acara disekolah. Promosi jasa bimbingan belajar di Lembaga Primagama juga dilakukan oleh pelanggan yang telah bergabung di lembaga primagama dengan melakukan informasi secara mulut ke mulut (word of mouth-WoM).

Tjiptono (2011:41) menyatakan, “ Tempat merupakan keputusan distribusi menyangkut kemudahan akses terhadap jasa bagi pelanggan potensial”. Lembaga bimbingan belajar Primagama menentukan syaratsyarat tertentu terkait dengan penempatan lokasi lembaga berada di wilayah kota dan ditepi jalan raya dilalui kendaraan umum karena menyangkut kemudahan akses bagi siswa agar dapat berminat bergabung dengan Lembaga Primagama. Hasil dari penyebaran angket yang telah diberikan kepada siswa Lembaga Primagama menyatakan bahwa lokasi Lembaga Primagama strategis, Lembaga Primagama mudah dijangkau dengan transportasi umum, dan penempatan lokasi bimbingan belajar Primagama berada di wilayah kota. Hal tersebut memberikan pengaruh yang signifikan terhadap keputusan siswa menggunakan jasa bimbingan belajar di Lemabaga Primagama.

Indikator terkait harga/ biaya yang diberlakukan oleh lembaga Primagama juga dapat memberikan pengaruh terhadap keputusan memilih mengunakan jasa layanan bimbingan belajar tersebut. Konsumen dapat terpengaruh untuk memutuskan menggunakan jasa bimbingan belajar primagama karena kesesuaian dengan kemampuan dan juga adanya diskon atau potongan harga yang diberikan oleh Lembaga Bimbingan Belajar Primagama. Diskon atau potongan harga diberikan kepada siswa primagama yang melakukan pembelian berulang atau siswa baru yang mendaftar ketika adanya event-event khusus yang diselenggarakan oleh bimbingan belajar Primagama. Lembaga Primagama Cabang Jember tidak mengenakan biaya pendaftaran dan biaya bimbingan secara terpisah dikarenakan lembaga menerapkan sistem paket yang dapat diangsur.

Tingkat profesional dan kecakapan tentor dalam memberikan bimbingan belajar serta kemampuan tentor dalam menjelaskan materi pelajaran kepada siswa menjadi pertimbangan siswa Primagama untuk memutuskan menggunakan layanan jasa pada lembaga Primagama. Lembaga Primagama menentukan standar yang ditetapkan kepada tentor dan karyawan agar dapat diterima oleh pelanggganya sehingga penilaian siswa terhadap tentor dan karyawan lembaga Primagama dapat berpengaruh positif. Hal ini diketahui dari pemaparan hasil wawancara salah satu responden berikut:

"Tentor dan karyawan di Lembaga Primagama ramah dan terkesan humble kepada siswa sehingga saya sebagai siswa merasa nyaman selama belajar di Primagama, para tentor juga menguasai materi sesuai dengan mata pelajaran, apabila saya mempunyai kesulitan dalam materi belajar mereka dapat membantu membimbing saya memahami materi yang saya anggap sulit hingga saya dapat memahami materi tersebut”. (Az, 17 Tahun) 
Lingkungan fisik adalah suatu hal yang secara nyata mempengaruhi keputusan untuk membeli dan menggunakan produk jasa yang ditawarkan (Zeithaml dan Bitner dalam Yazid, 2008:19). Konsumen akan menjadikan kondisi lingkungan fisik dari lembaga sebagai salah satu pertimbangan dalam untuk memutuskan menggunakan jasa bimbingan di Primagama. Berdasarkan hasil dari jawaban angket yang telah disebar oleh peneliti, siswa primagama sangat setuju jika keputusan mereka memilih lembaga bimbingan primagama karena lingkungan belajar mereka yang bersih dengan suasana dan desain ruang yang nyaman untuk melakukan pembelajaran. Berikut hasil wawancara yang dilakukan peneliti dengan salah satu responden dalam penelitian ini.

"Menurut saya tata letak desain ruangan di lembaga bimbingan belajar Primagama bagus dan memberikan kesan semangat serta fokus untuk belajar. Saya pernah masuk ke lembaga bimbel lain selain Primagama menurut saya desain ruang di lembaga bimbel lainnya terkesan membosankan. Desain tata ruang di primagama dicat warna-warni sehingga saya tidak bosan belajar disini”. (Af, 17 tahun)

Indikator proses pada bauran pemasaran dapat memengarui keputusan siswa menggunakan lembaga Primagama terkait dengan proses awal ketika siswa menginginkan informasi terkait lembaga Primagama sampai pada proses akhir siswa memeroleh bimbingan. Proses untuk bergabung di Lembaga Bimbingan Belajar Primagama Cabang Jember diberikan kemudahan dan tidak memakan waktu yang lama. Siswa yang telah memutuskan untuk mendaftar dapat langsung mengikuti bimbingan belajar sesuai dengan jenjang kelas. Lembaga Bimbingan Belajar Primagama Cabang Jember melakukan proses kegiatan bimbingan pembelajaran dimulai pada pukul 16.00 - 20.00 WIB yang dibagi menjadi 2 sesi. Pembelajaran juga bisa dilakukan diluar kelas dengan layanan yang disebut E-Learning Management System (EMS). Layanan EMS dapat diakses 24 jam oleh siswa melalui internet yang berisi tentang video tutorial belajar mata pelajaran yang dibutuhkan oleh siswa Primagama. Proses pelayanan lembaga Primagama dilakukan hingga hasil belajar siswa juga akan dipantau oleh pihak lembaga sehingga dapat melakukan tindakan evaluasi untuk memperbaiki kekurangan/meningkatkan hasil belajar siswa selanjutnya melaui program yang disebut smart consys. Smart consys yaitu sebuah software yang dirancang untuk memantau, menganalisis, dan mengarahkan siswa/i dalam perkembangan prestasi akademik.

Variabel Bauran pemasaran yang menjadi salah satu salah satu faktor yang sering dilakukan sebagai rangsangan untuk memengaruhi pertimbangan konsumen sebelum melakukan keputusan. Indikator-indikator dari 7P bauran pemasaran di atas dapat membuat responden untuk terpengaruh menggunakan layanan jasa bimbingan belajar yang ditetapkan oleh Lembaga Primagama. Pada umumnya siswa menginginkan kemudahan proses yang dilakukan dari awal mereka mendapatkan informasi mengenai lembaga primagama sampai pada hasil akhir setelah mereka menggunakan jasa tersebut dapat terpenuhi. Faktor dari indikator bauran pemasaran lainnya juga menjadikan pertimbangan oleh siswa untuk menggunakan layanan bimbingan belajar tersebut. Bauran pemasaran yang diperhatikan oleh siswa diantaranya adalah produk atau program bimbingan belajar yang terdapat pada bimbingan belajar Primagama, promosi, lokasi, harga, sumber daya manusia/orang, bukti fisik dan proses yang dilakukan pada bimbingan belajar Primagama Cabang Jember.

\section{PENUTUP}

Berdasarkan hasil penelitian dan pembahasan mengenai pengaruh bauran pemasaran terhadap pengambilan keputusan menggunakan jasa bimbingan belajar Primagama Cabang Jember dapat disimpulkan bahwa ada pengaruh yang positif antara bauran pemasaran terhadap pengambilan keputusan menggunakan jasa bimbingan belajar Primagama Cabang Jember. Adapun besarnya persentase pengaruh variabel bauran pemasaran terhadap pengambilan keputusan menggunakan jasa bimbingan belajar primagama sebesar $83,1 \%$.

Berdasarkan kesimpulan di atas, maka penulis memberikan saran kepada beberapa bagi pihak lembaga, hendaknya meningkatkan indikator-indikator terkait bauran pemasaran agar dapat memertahankan dan dapat mempengaruhi keputusan siswa lain untuk menggunakan jasa bimbingan belajar di Lembaga Primagama. Serta saran bagi peneliti selanjutnya diharapkan untuk menentukan variabel bebas lain yang tidak turut diteliti dalam penelitian ini. 


\section{DAFTAR PUSTAKA}

Alma, B. 2014. Manajemen Pemasaran dan Pemasaran Jasa. Bandung: Alfabeta.

Alma \& Hurriyati. 2008. Manajemen Corporate \& Strategi Pemasaran Jasa Pendidikan.Bandung: Alfabeta.

Lupiyoadi, R. 2013. Manajemen Pemasaran Jasa. Jakarta: Salemba Empat.

Nitisusastro, M. 2013. Perilaku Konsumen Dalam Perspektif Kewirausahaan. Bandung: Alfabeta.

Tjiptono, Fandy. 2011. Pemasaran Jasa. Jatim: Banyumedia.

Yazid, 2008. Pemasaran Jasa Konsep dan Implementasi. Yogyakarta: EKONISIA.

Yusuf, S \& Nurihsan, J. 2012. Landasan Bimbingan \& Konseling. Bandung: PT.Remaja Rosdakarya. 